\title{
CULTURA DE QUALIDADE E EFICÁCIA DURÁVEL: O PRIMADO DA GESTÃO DE PESSOAS
}

\begin{abstract}
Resumo: $O$ texto procura explanar a filosofia, a pedagogia e a prática de implementação de um projeto de mudança $e$ desenvolvimento organizacional através de um estudo de caso de uma unidade industrial, integrada nessa época (1988/90) na estrutura da sub-holding Portucel Embalagem (a qual integra o universo EUROPAC, desde 2000). Revisita-se uma situação real, ocorrida numa época em que se davam os primeiros passos em ordem a uma mudança no paradigma de gestão pela qualidade total num país confrontado com a recente integração num espaço concorrencial extremamente agressivo (a CEE). Procurava-se testar na prática de terreno os princípios de uma gestão alternativa à designada gestão tradicional, eivada de princípios inspirados na teoria tayloristal fayolista (Lopes, 2012), promotora de uma ideia de mudança programada e conduzida segundo os parâmetros da integração hierárquica. Justifica-se este exercício de revisitação pela falta de casos empíricos no nosso ensino de ciências de gestão em geral, e de gestão estratégica de recursos humanos em particular, por um lado e, por outro, porque o quadro mental dos empresários e gestores portugueses continua preso às construções teóricas e práticas, inspiradas no primado da liderança autocrática e na estrutura burocrático-mecânica tradicionais. O trabalho conjuga três leituras sobrepostas: o que se passou no terreno, os instrumentos teóricos e as ferramentas de investigação/ação disponíveis, bem como as reflexões que se podem fazer hoje, acerca das mesmas matérias, a partir de uma atualização bibliográfica. Fica claro que a mudança profunda é possivel, que esta pode fazer-se apesar de se trabalhar com pessoas dotadas de fracas habilitações literárias e que tem um custo-benefício extraordinariamente favorável.
\end{abstract}

Albino Lopes

Palavras-chave: Mudança Organizacional; Cultura Organizacional; Liderança; Gestão pela Qualidade Total (TQM); Dispositivo de Intervenção.

1 Professor Catedrático, do Instituto Superior de Ciências Sociais e Políticas da Universidade de Lisboa. Email: alopes@iscsp.ulisboa.pt 


\title{
Title: CULTURE OF QUALITY AND DURABLE EFFECTIVENESS: THE PRIMACY OF MANAGING PERSONS
}

\begin{abstract}
The article aims to explain the philosophy, pedagogy and practice of implementing a change project and organizational development through a case study of an industrial manufacture, integrated at that time (1988/90) in the structure of the sub-holding Portucel Packaging (which integrates the EUROPAC universe since 2000). A real situation was revisited, which occurred during a period when Portugal was given the first steps in order to change the paradigm of total quality management in a country faced with the recent integration in an extremely aggressive competitive space (EEC). The objective was to test in the field the principles of an alternative management to the designated traditional management, riddled principles inspired by Taylorism / Fayolism theory (Lopes, 2012), sponsoring of an idea of programed change and conducted under the orientation of the hierarchical integration. On the one hand the exercise of revisiting was justified by the absence of empirical cases in teaching management sciences in general, and strategic management of human resources in particular and, on the other hand, because entrepreneurs and Portuguese managers mental framework was still trapped to theoretical constructs and practices inspired by the rule of autocratic leadership and bureaucratic-mechanical structure traditional. The work combines three overlapping reads: what happened on the field, the theoretical instruments and tools of research / action available, as well as the reflections that can be made today about the same matters from an updated review. It is clear that deep change is possible, that this can be done while working with people endowed with weak educational background and has an extraordinarily favorable cost-benefit.
\end{abstract}

Keywords: Organizational Change; Organizational Culture; Leadership; Total Quality Management (TQM); Dispositive Intervention

\section{INTRODUÇÃO}

O caso aqui apresentado pode ser explorado em situação de sala de aula; pode ser consultado, ainda, a este respeito, o artigo dos investigadores intervenientes (Lopes, Reto e Nelson, 1989). Pretende-se, com o caso, ilustrar, nomeadamente, a relação entre Mudança Profunda e Mudança Contínua (kaizen), e como uma decorre da outra, com vista a dotar a empresa de uma capacidade autónoma de mudança contínua. É igualmente apresentado, de forma telegráfica, o modelo de implementação da mudança de uma estrutura hierárquica para uma 
comunidade de trabalho, flexível e colaborativa, envolvendo transformações dramáticas na cultura existente, nas relações e nas competências, em ordem a uma liderança da cultura em rede.

\section{NEGOCIAÇÃO DO PROGRAMA}

Reformulação do pedido inicial - escolher a opção Leiria (onde se localizava a mais moderna e melhor fábrica da Portucel Embalagem) para lançar um programa de desenvolvimento de "círculos de qualidade" de K. Ishikawa, com vista a criar as condições de mudança, igualmente, previstas no modelo de Ph. Crosby, ou de "defeito zero" - e posterior decisão de começar pela fábrica mais problemática, aquela que levantava dúvidas à própria Administração acerca das condições de êxito. A razão da descrença apoiava-se nos habituais mitos da baixa escolaridade, de uma mentalidade mais rural do que operária, do radicalismo de esquerda, etc. - presentes, desde o início, na fábrica de Sintra/Albarraque. Falamos de mitos em sentido negativo, dada a possível reversibilidade das situações evocadas: a hostilização sindical pode ser controlada pela dignificação da comissão de trabalhadores, como depois se verificou e se confirmaria posteriormente no sucesso da Autoeuropa; ou dos valores da ruralidade do Japão tradicional e pobre que foram a base do êxito da gestão pela cultura do Japão.

O acordo traduzia-se pela opção por um mix dos modelos do D.O. (Desenvolvimento Organizacional) e do "elevado envolvimento dos trabalhadores", suportados na abordagem teórica da Excelência em Gestão (em que não estão predefinidos objetivos ou standards, a abordagem se nutre interna ou externamente na noção das melhores práticas em Gestão das Pessoas, o programa de ação se constrói com uma participação progressivamente estendida a todos, instituindo-se como objetivo último o princípio da inversão da pirâmide hierárquica - bottomup), a partir da experiência da equipa de investigadores do ISCTE, desenvolvida numa empresa congénere, de estatuto cooperativo - UNOP -, experiência de envolvimento e mudança de atribuição causal, nos indivíduos aderentes ao projeto de gestão participativa da cooperativa em causa conforme Reto e Lopes (1988), artigo em que se propõe uma designação alternativa à de círculos de qualidade - a de grupos de desenvolvimento, para promover a "destruição criativa" schumpeteriana (Schumpeter, 1997), através do envolvimento das equipas 
semiautónomas, assumidas como verdadeiros núcleos de empreendedores internos, capazes de: (i) conceber novos bens de consumo; (ii) novos métodos de produção ou de transporte; (iii) entrar em novos mercados; (iv) conceber novas formas de organização da produção; (v) promover o desenvolvimento organizacional (passar da produção artesanal à situação de conglomerado/rede empresarial).

Mudar significava, assim, no nosso entender, promover a abertura de espaços de questionamento das oito dimensões mais relevantes de uma abordagem complexa da noção de organização: (i) relações de poder (opção pelo empoderamento ou capacitação de todos os atores inseridos na cadeia de valor); (ii) liderança (consciência dos desafios colocados pela evolução do meio, das relações de poder e da gestão do reconhecimento); (iii) gestão (relacionamento com a hierarquia e métodos de enquadramento); (iv) cultura (processos de socialização, clima, código de ética e valores organizacionais); (v) estratégia (missão, visão, objetivos e padrões de qualidade); (vi) estrutura (organização formal, regras de funcionamento); (vii) gestão das contradições entre tecnologia e emprego; (viii) gestão do comprometimento das pessoas (atitudes, motivações, competências, stresse e contrato psicológico).

Optar-se-ia, enfim, por um programa de Investigação/ Ação (I/A), por fases.

i) Fases propostas: (i) diagnóstico e formação do vértice estratégico ${ }^{2}$ da coordenação bicéfala da Portucel Embalagem que superintende a Divisão de Vendas Sul e a unidade fabril de Albarraque; (ii) formação de dirigentes de primeira linha, ou de Gestão Intermédia (consciência da importância da noção que, entretanto, temos desenvolvido, de sistema de liderança da cultura para explicar o êxito do sucesso japonês - uma tradição de cultivo cooperativa (até porque se trata de terrenos em socalco) do arroz e de práticas da autodefesa das populações sob a supervisão/formação dos samurais de onde derivaria uma cultura de liderança confiável, de acordo com a análise de Morgan (1986); (iii) formação e desenvolvimento do trabalho em equipa de base (conjugação

\footnotetext{
2 A razão de ser desta preocupação com o vértice estratégico prende-se com um alerta de Kets de Vries e Miller (1984 e 1990) dizendo que o sucesso de uma mudança organizacional se prende com a capacidade dos dirigentes para suplantar a sua própria resistência à mudança. A formação que os autores propõem constaria de um processo de desocultação de razões subjacentes, pelo que se deveria trabalhar com base em confronto, em clarificação e em interpretação (dos aspetos relevantes encontrados em sede de diagnóstico). Kotter (1995): um processo de mudança depende em 80\% da liderança e $20 \%$ da gestão.
} 
do efeito de escala com a pequena unidade produtiva - desenvolvimento da rotação autónoma de funções e/ou do intra-empreendedorismo, pois, de acordo com Philippon (2007), a satisfação no trabalho está associada ao empreendedorismo ou à rotação interna de tarefas.

ii) Elaboração de um contrato de 2 anos, por períodos de 6 meses para cada fase, por parte da Administração da Holding da Portucel com o Departamento de Gestão do ISCTE para disponibilizar uma equipa de quatro investigadores, renegociável no final de cada período com a aprovação de um relatório de progresso, com a duração de 2 anos. O valor total do contrato (imediatamente denunciado a nível interno como exorbitante!) era de 6.000 contos (ou seja, 30.000 Euros).

O comprometimento inequívoco do topo estratégico ao mais alto nível (considerada a condição necessária) parecia uma garantia firme para que a mensagem pudesse ser clara, muito embora a participação no projeto fosse voluntária. De notar que a estrutura de vendas era comum a Albarraque e a Leiria, situação que se revelava muitíssimo problemática para uma intervenção conjunta com a fábrica de Albarraque. Esta situação exigia uma gestão criteriosa do conflito intergrupos (ingroup ou endogrupo - outgroup ou exogrupo) que existia entre as duas estruturas, conforme Vala et al. (1987) e Vala (1997).

iii) No que respeita á metodologia do trabalho a desenvolver, especificamente no terreno, procurávamos uma aproximação à pesquisa interativa. A metodologia de pesquisa interativa aproxima-se de uma situação etnográfica de tipo clínico, que se traduz numa atuação a partir do sentido que os atores de terreno conferem às situações encontradas, na sua singularidade e a partir dela, uma espécie de "oportunismo metódico", como alguns a designavam (Collard e Suquet, 2013). Não se aceitava seguir, deste modo, um protocolo estabelecido antecipadamente, apesar da insistência da Administração, mais habituada à maneira de proceder da generalidade dos consultores, na medida em que era necessário trabalhar de acordo com as circunstâncias, as necessidades, as oportunidades, as impossibilidades ou as negociações, forçando constantes inflexões, na medida em que os atores organizacionais teriam de sentir que tinham uma palavra a dizer sobre o desenrolar da intervenção. 


\section{DESENHO DE UMA ESTRUTURA DE SUPORTE À INVESTIGAÇÃO/ AÇÃO.}

Tratava-se de criar uma cultura de mudança contínua, aproveitando as condições propícias da mudança episódica contratualizada, numa estrutura empresarial que parecia descuidada face às mudanças decorrentes da recente adesão ao Mercado Único Europeu/CEE e que estava a tornar os ambientes instáveis, os nichos de negócios, raros e as oportunidades diminutas (Mintzberg, Ahlstrand e Lampel, 1999). Beer, Eisenstat e Spector (1990) alertavam, entretanto, que um processo de mudança eficaz devia ser ancorado na mobilização dos colaboradores, no desenvolvimento de um consenso sobre as atitudes de mudança e sobre a formação dos trabalhadores para a ação, pois se tratava de lidar com um paradoxo que só o envolvimento dos próprios permite resolver: não se pode mudar o que as pessoas fazem porque provoca resistência e apenas se pode conduzir a mudança no interior da própria rotina instalada.

O projeto orientava-se, de preferência, para um figurino de Investigação/Formação. De acordo com a psicologia construtivista, pretendia-se dar uma mensagem clara segundo a qual as condições da mudança organizacional estavam dentro da empresa e competia ao processo formativo revelar essas condições: conduzir os trabalhadores, aos diversos níveis da hierarquia, a desejarem coletivamente a mudança e a acreditarem nas suas capacidades para acederem à excelência organizacional, a partir de mudanças mínimas e participadas. Para o efeito, importava criar um dispositivo organizacional facilitador da mudança profunda a implementar.

2.1. O dispositivo de intervenção pode ser entendido como um subsistema (mediador flexível - espécie de rede estabelecida entre elementos internos e externos, destinado a poder acolher a surpresa e o aleatório) que se revela determinante pelo facto de estabelecer novas linhas de comunicação transversais (anti hierárquicas) face à situação anterior e que permitem uma reorientação do todo organizacional para finalidades precisas. Um dispositivo organizacional seria, assim, uma espécie de nó de relações que permitiria perceber, orientar, determinar, intercetar, modelar, controlar e assegurar os gestos, as condutas, as opiniões e os discursos dos indivíduos. Lascoumes (2004) invoca K. Weick e afirma que o mérito de um dispositivo é o de permitir ver por detrás da racionalidade aparente das organizações e impor regras tácitas que revelam as contradições ou as verdadeiras significações em termos de 
poder e de difusão dos modelos cognitivos em uso. Conclui que os dispositivos se compõem de um conjunto de três elementos: um substrato técnico, uma representação esquemática da organização e uma filosofia gestionária. Sendo a cultura portuguesa de natureza adaptativa (Lopes, 2010), um dispositivo de participação impõe-se, pois, para vencer a resistência à participação, quer dos dirigentes, quer dos trabalhadores. $\mathrm{O}$ dispositivo pode assumir diversas fórmulas, mas ele será sempre necessário enquanto "máquina" destinada a permitir ver (mindfullness), de fazer dizer (sensemaking), de criar espaços de acesso ao poder (empowerment) e de afirmação do sujeito (enactment) na sua radical individualidade atuante na criação do contexto, de acordo com a revisão de literatura efetuada por Mabi (2011). Este dispositivo de intervenção era formado por três subgrupos e que deveriam constituir uma equipa de trabalho, modelo do desenvolvimento organizacional futuro: (i) grupo externo de formadores/consultores (estatuto de professores da universidade); (ii) grupo (interno) de dois quadros técnicos facilitadores (o responsável pelo laboratório de qualidade da fábrica e a responsável pela formação da sub-holding); (iii) dois estagiários, a tempo integral, com perfis académicos adaptados à função de Animação de Equipas (uma licenciada em psicologia, vertente social), e de Produção de Indicadores (um licenciado em gestão), em que a seleção deste segundo elemento (apesar de todo o cuidado processual) não se revelou positiva ao invés do caso da psicóloga que se revelaria de nível excelente, tendo-se assumido, mais tarde, como se fora uma "empreendedora da mudança organizacional", no sentido de Moisdon (2008).

Uma cultura de equipa (Katzenbach \& Smith, 1993) equivale a: (i) promover a partilha/circulação da liderança na base do centro operacional, suportada na ideia da complementaridade dos seus membros; (ii) responsabilizar todos e cada um dos colaboradores do grupo, através de reuniões (formativas) regulares; (iii) aprender a medir a eficácia (com recurso à estatística e à contabilidade de custos, sobretudo os ocultos) de maneira direta, grupo por grupo, à medida que avançasse o esforço organizativo por grupos - círculos de desenvolvimento; (iv) promoção da discussão dos problemas, decisão e execução, no seio dos grupos, como se de uma microempresa se tratasse.

2.2. O estatuto dos estagiários era inspirado na metodologia a privilegiar, ou seja, a da "observação participante" durante todo o 
desenrolar da intervenção e de continuadores do programa, após o términus do contrato da empresa com os investigadores.

2.3. O estatuto dos investigadores é, neste contexto, relevante pelo que se justifica refletir sobre o seu papel específico de intervenientes que optam pela I/A, de forma a poder inferir-se sobre o bem fundado ou não desta opção pelo seu estatuto e o da equipa - simultaneamente externo e facilitador da observação participante. Para Barbier (1996), os investigadores nesta modalidade de I/A designada de "existencial e transpessoal" porque aberta ao sentido que as pessoas dão (e apenas elas podem querer dar) à sua atividade de trabalho, desenvolvem o seu papel profissional/científico no contexto de uma situação paradoxal em que se conjugam linguagem rigorosa e metafórica, distanciamento e comprometimento, racionalidade e afetos, mediação e propostas, formação e autoformação, ciência e arte. Não se assumem nem como agentes institucionais ou atores organizacionais, mas também não se trata de indivíduos sem pertença; pelo contrário aceitam todos estes papéis ou cada um deles, de acordo com as fases e os desenvolvimentos da ação ou da reflexão. São antes de tudo sujeitos autónomos, e mais ainda autores da sua prática e do seu discurso. O processo de autonomização em que se movem condu-los a liderar uma equipa interventora interna no seio da qual se vão desenrolar os conflitos e os imprevistos do confronto/tensão entre a situação e a improvisação (Weick, 1998), e que a opção pela estratégia participativa aceite pela liderança institucional permitem.

\section{PROGRAMA DE COMUNICAÇÃO (dimensões mais relevantes)}

3.1. Circulares concebidas para difundir e sustentar uma filosofia de gestão pela qualidade suportada no desenvolvimento organizacional e nos fundamentos da Gestão Estratégica de Recursos Humanos).

3.2. Escuta ativa, na aceção de Thomas Gordon, referido por Talvio et al. (2013) - método que continua a ser estudado, nomeadamente na Finlândia, o país líder mundial na eficácia educativa -, em coerência com uma comunicação persuasiva centrada na missão da empresa, na cultura grupalista e nos princípios de gestão sociotécnica (participação e subsidiariedade).

3.3. Criação de um "logotipo" (e de um "slogan", sob a forma de assinatura) entendido como elementos base de suporte do programa, inspirados nos valores declarados e na ideia de força interna, representada pela sigla $\mathrm{CD}$, projetada por dois vórtices, ou seja, uma estratégia baseada 
nos recursos internos. Foi utilizada uma figuração criada coletivamente, a partir da sigla $\mathrm{CD}$ e de espirais desencontradas que nasciam de cada uma das letras (Círculos de Desenvolvimento), rodeada por dois círculos concêntricos, onde se lia "Todos no Êxito da Nossa Embalagem". O slogan evoca a ideia de diálogo iterativo (ou transcultural) dos valores (Sainsaulieu, 1977) de união, de mérito, de inclusão e de profissionalismo, propondo a construção de uma redefinição da identidade da empresa orientada para o futuro. Efetivamente, evocava-se a condição: (i) "Todos", envolvendo um comprometimento sem limites, mesmo se a participação no programa era voluntária (propósito central da subcultura da administração); (ii) "Êxito", evocando o sentido de realização; (iii) "Nosso", evocando um valor sindical de elevado significado para os trabalhadores (o princípio da não exclusão da subcultura sindical); (iv) "Embalagem", evocando o produto/serviço e o elemento central da marca distintiva da empresa (subcultura diretiva). Este slogan constituía uma solução de um autêntico "diálogo transcultural" entre as diversas culturas profissionais presentes na empresa. O logotipo contrapõe ainda a figura circular, como estrutura igualitária e englobante, face à mais tradicional de pirâmide hierárquica. Os círculos concêntricos evocam, enfim, a ideia de dinamismo e de expansão da rede a toda a cadeia de valor. Acrescente-se que o slogan e o logotipo criados funcionavam como uma espécie de marca interna, com hipótese de expansão a toda empresa, a PORTUCEL E. P. (atualmente, The Navigator Company). Ver, a este propósito, Seruya (2009).

3.4. Boletim especialmente consagrado ao apoio do programa para refletir as posições dos grupos que se iriam formando.

3.5. Aproveitamento das críticas da Comissão de Trabalhadores ${ }^{3}$ (nomeadamente uma sátira muito violenta, sob a forma de cartoon, contra a separação entre o grupo das vendas e da produção, em que as duas divisões estavam separadas por um fosso profundo, cheio de água, povoada com crocodilos e uma barreira de canas de bambu afiadas, sendo a comunicação entre as margens feita por uma escada de parede encostada a uma outra lançada da margem inversa) para legitimar o pensamento divergente e daí passar à posição de crítica construtiva,

\footnotetext{
${ }^{3}$ A ligação à CT representava uma hipótese de se poder vir a contornar a situação de um conflito sindical crónico (ela própria derivada da dispersão sindical e à situação decorrente do acordo de empresa, imutável sem o consenso entre todas as partes envolvidas) embora a equipa externa estivesse proibida de contactos formais, dada a convicção (mútua!) da inutilidade do contacto.
} 
facilitada pela criação do "Boletim dos Círculos de Desenvolvimento", possível após se verificar que ninguém lia nenhum dos quatro boletins internos.

3.6. Concurso de ideias aberto a todos. O envolvimento de todos visava prevenir o isolamento dos grupos minoritários ativos, que pudessem ir surgindo, por parte do grupo maioritário. Quando bem gerida, esta aposta em grupos minoritários revelou-se eficaz, tendo contribuído para a motivação dos trabalhadores, que se reviram no fenómeno de aceitação das ideias pelas chefias, criando-se, desta forma, uma nova atitude. Esta ideia vai de encontro à perspetiva das minorias ativas de Moscovici (Moscovici e Zavalloni, 1969) mostrando que pequenos grupos têm a capacidade de influenciar os restantes modificando as suas atitudes. Ainda segundo Moscovi e Lage (1976), a minoria pode influenciar as estruturas e normas implícitas, sendo o seu efeito superior ao da maioria. Esta influência não ocorre devido à competência ou posição de liderança dos indivíduos que constituem a minoria, mas sim através da convicção e coerência, alcançando as minorias consistentes um reconhecimento social das suas qualidades, o que faz com que outros indivíduos as considerem como agentes de influência.

3.7. Exploração dos êxitos coletivos, à medida que se passava algo que pudesse configurar "um pequeno passo" em ordem à consolidação da gestão participativa, ou seja, uma procura do "efeito de Pigmaleão positivo", teorizado, entre outros autores, por Tap (1998).

3.8. A base do programa de comunicação assume o princípio da contraposição entre o símbolo do "círculo" e o da "pirâmide" hierárquica, sabendo-se que este está tradicionalmente mais associado à noção de empresa ou de organização em geral, juntamente com a justificação de uma designada "assinatura", elaborada a partir de um diálogo de valores profissionais (Sainsaulieu, 1977). Este princípio visava também questionar a integração hierárquica, sem fragmentação da empresa, através da ideia de integração pela noção de rede, para transformar as relações com unidades integradas pelo mercado (caso dos desenhadores e dos motoristas subcontratados, entre outros). Pretendia-se responder a um desafio que a empresa estava a enfrentar, vindo dos designados cartonageiros, que tinham fortemente degradado a quota de mercado da Portucel Embalagem, encontrando-se dessa forma, uma resposta eficaz a essa ameaça. Fukuyama (2000) constatava que as grandes empresas 
hierarquizadas foram, nos anos 80, nos EUA, vítimas de competidores mais pequenos, mais rápidos e mais ágeis.

Procurava-se, acima de tudo, garantir uma comunicação inclusiva, que não deixasse margem alguma para qualquer divisão da organização, ou mesmo entre elementos da cadeia de valor, para uma linguagem do tipo "nós" e "eles", própria de uma cultura (de empresa) fragmentada em dois níveis horizontais.

A criação amplamente participada desta marca interna constituiu, ainda, uma base imprescindível para a criação de um clima de confiança ao nível das relações laborais, permitindo aos trabalhadores olhar para o processo de mudança em curso como uma oportunidade de participação e não como uma ameaça. Os resultados foram surpreendentes, porquanto verificar-se-ia, mesmo, uma compatibilização da fórmula participativa, entretanto desenvolvida, com um espírito sindical fortemente vincado e associado à CGTP-IN, em linha com o que se viria a verificar alguns anos depois através da fórmula da cogestão na Autoeuropa, e entre outras empresas multinacionais. A empresa e a própria unidade produtiva (fábrica de Albarraque) puderam ser entendidas como um espaço de colaboração e não já como espaço de confronto de interesses e de luta de classes protagonizada pela instância sindical. Como diria Olins (2003), falando precisamente do potencial gerador de adesão das marcas, o importante não são os produtos ou os serviços em si, mas a adesão a um ideal. Pensamos que a marca (C D desenhados de forma a criar dois vórtices - de círculos de desenvolvimento) ou mesmo o slogan escolhido (que a acompanhava) possuía a força necessária para despertar um sentimento para com a empresa, por parte dos colaboradores entendidos como os seus clientes internos e, do nosso ponto de vista, correspondia igualmente aos requisitos que a investigação de Neumeier (2003) viria a definir para uma marca: (i) distintiva; (ii) breve; (iii) apropriada; (iv) fácil de pronunciar; (v) empática; (vi) extensível a todas as unidades do grupo empresarial.

Para uma compreensão das sete características do processo de elaboração da marca interna "Círculos de Desenvolvimento - Todos no Exito da Nossa Embalagem", é curioso ver como o desenho do logo e a assinatura da marca criada parecem dar conta das preocupações que Robbins (1996) encontrou, noutros casos de estudo, com os mais diversos artefactos culturais, teorizados por Schein (1992). Por sua vez, os elementos do logo procuram um alinhamento potencial da comunicação 
interna da organização. Segundo Robbins (1996) seriam sete as características básicas que podem ter um efeito agregador e revelar a essência da cultura de uma empresa expressa num Logo (princípio da condensação): (i) iniciativa/inovação e assumção de riscos; (ii) atenção a detalhes pertinentes; (iii) orientação para resultados (expansividade); (iv) orientação para equipas (círculos/cooperação); (v) orientação para as pessoas (desenvolvimento); (vi) agressividade; (vii) estabilidade (delimitação).

Com a criação de uma marca interna, pretendia-se gerar um clima de confiança laboral transformando o processo de mudança num espaço de colaboração com o qual os trabalhadores se poderiam identificar. A marca interna assim desenvolvida pode ser considerada uma marca mista, na medida em que é constituída por um elemento nominativo (uma ou várias palavras) e um elemento gráfico (uma ou várias imagens), tendo deste modo uma estrutura mais complexa do que é habitual.

\section{DEFINIÇÃO DA ESTRATÉGIA DE MUDANÇA}

4.1. Noção de partida: teoria do campo de forças organizacional (Lewin, 1959).

4.2. As três etapas da Mudança Episódica e/ou Profunda.

4.3. A sequência das etapas inverte-se, na passagem à Mudança Contínua ou de tipo evolutivo, em que a mudança cognitiva tende a ocorrer em contínuo, ao contrário da fórmula inicial.

É de salientar que, de acordo com a noção lewiniana originária, um "todo" (holístico ou organizado), um "sistema" - Ervin Laszlo afirma no prefácio à edição em francês de Bertalanffy (1993) que o interesse pela teoria dos sistemas é estimulado, nomeadamente, pela necessidade que todos sentimos de dispormos de teorias gerais nas ciências naturais, nas sociais, ou mesmo nas tecnológicas -, obedece ao primado da globalidade (ao contrário do que afirmava a teoria cartesiana do primado da análise) e tende sempre para o equilíbrio (cada vez que se induz mudança, o retorno à estabilidade impõe-se), obrigando a novos ciclos de readaptação. Estes ciclos, tratando-se da gestão de pessoas, poderiam ser definidos da seguinte maneira: iniciativa/inovação, adesão das pessoas (tirar partido da cultura nacional, fortemente marcada pelo coletivismo), formalização e reelaboração da estrutura, em novos ciclos evolutivos de melhoria, sob a supervisão e a salvaguarda da lei ou do pacto de empresa (dimensão 
política da empresa, de acordo com Quinn \& Cameron; 1983 e Quinn, 1996).

As questões da mudança são perspetivadas por Pettigrew, Woodman e Cameron (2001), como um imenso problema por resolver que continua por resolver no seio das ciências sociais: quem a pode promover, quais as motivações, as competências e a capacidade de aprendizagem dos atores envolvidos nesses processos e que condições a promovem, interrogavamse os autores, num artigo bastante fundamentado e que continua a ser amplamente citado.

O esquema teórico dos processos de mudança episódica, seguido por nós, era o de Lewin (1959), baseado na teoria do campo de forças, e que redesenhámos como uma sequência de fases: cognitiva (descristalização); afetiva (deslocação); emotiva (recristalização).

4.4. Mas o processo também poderia ser visto pelo ângulo inverso: procurar boas práticas ou ideias já existentes internamente. Pela importância, o ponto da mudança será desenvolvido de modo específico.

Este esquema original de $\mathrm{K}$. Lewin foi depois, efetivamente reinterpretado, para servir de suporte à mudança contínua, suportada na ideia de partir das próprias ideias dos atores de terreno, como viriam a recomendar Weick e Quinn (1999), cerca de uma década depois da experiência. De facto o modelo alternativo de Weick e Quinn parece estar mais em consonância com a estratégia emergente, seguida efetivamente pelo grupo de intervenção no caso em estudo.

Não podíamos dispor ainda do conselho de Mintzberg e Westley (2001), que afirmam que a teoria do "doing first" foi desenvolvida por Karl Weick, por meio do modelo: ação-seleção-retenção. O que significa fazer várias coisas (princípio da percolação), procurar descobrir depois as que funcionam e fazem sentido, para em seguida repetir os comportamentos que garantem o sucesso. Segundo os autores não pensamos para depois agir; agimos e só depois o pensar faz sentido. Um problema coloca-se, entretanto: o de um sentido de urgência que induz à ação (Kotter, 1996), em que o autor desenvolve todo um programa de mudança em oito etapas, que parece complementar o que se expôs acerca de Weick e Quinn (1999): (i) criação de um sentido de urgência que facilite um generalizado desejo de ação; (ii) criar uma coligação de apoio e dotada das desejáveis condições de condução da mudança; (iii) promover uma visão partilhável da mudança a prosseguir; (iv) comunicar essa visão, tanto interna como externamente (junto dos restantes atores 
pertinentes); (v) remover os possíveis obstáculos através do empoderamento das pessoas; (vi) criar as condições indispensáveis para conseguir êxitos no curto prazo; (vii) consolidar os ganhos à medida que forem sendo obtidos; (viii) ancorar a mudança na cultura da organização. A maioria destas recomendações coincide, efetivamente, com linhas de ação que tivemos em atenção no nosso projeto, com exceção, por ventura do sexto item, acerca do qual não estávamos devidamente alertados. Esta abordagem é coerente com o facto de, no caso desta empresa, se ter aprendido pelo facto de se fazer e de que as estratégias foram emergindo mais da experiência do que apenas de um esforço de pensamento sistemático.

Os autores acima referidos argumentam também que, mesmo no caso do modelo mais conhecido para elaboração estratégica - o modelo SWOT em que são avaliam as forças e fraquezas, as oportunidades e ameaças poderia ser mais adequado se a organização se baseasse em experiências concretas internas do que em simples conjeturas.

4.5. Mintzberg e Westley (2001) consideram, ainda, que quando as organizações tendem a insistir no modelo de "Thinking First" através de um planeamento formal, em lugar do princípio de "doing first", estas correm o risco de acabar por desencorajar a própria aprendizagem dos colaboradores, dificultando, por consequência, a emergência de uma Learning Organization.

De acordo com Weick (2001), em lugar de se direcionar a atenção apenas para a tomada de decisão nas organizações, deveria dar-se mais atenção a pressupostos e esquemas de ação utilizadas pelas pessoas como recursos nos mesmos processos de decisão. Para este autor, efetivamente, a ação seria a ponte que reforça o compromisso dos membros de uma organização com os significados que partilham. Desse modo, qualquer ação é uma decisão, fruto de uma interpretação, mais do que de uma direção escolhida. Nesse sentido, ela é construída muito mais com base em experiências passadas, recombinadas por sua vez com a situação atual, do que em definições orientadas para o futuro.

4.6. Acerca do sucesso de processos de mudança atente-se num importante relatório da American Productivity Quality Center (APCQ, 1997), em que é efetuada uma análise muito detalhada das melhores práticas (através de uma metodologia de benchmarking) de gestão de processos de mudança em dez empresas americanas, tendo sido identificados os elementos-chave seguintes, tidos como responsáveis pelo sucesso dos casos estudados: (i) comprometimento claro com a mudança 
e participação ativa em todas as fases do processo, por parte da liderança de topo; (ii) conseguir desenvolver uma estratégia de mudança profunda ao nível da cultura/projeto organizacional; (iii) desenvolver um comprometimento ativo com a estratégia de mudança proposta, a partir dos colaboradores; (iv) uma reorganização do trabalho baseada nos princípios da autonomia; (v) uma aposta clara em programas estruturados de formação profissional contínua de forma a proporcionar aos trabalhadores um envolvimento ativo, propiciando-lhes uma maior autonomia no trabalho e uma crescente capacidade adaptativa, de modo a não haver lugar aos designados hiatos tecnológicos, como acontece frequentemente; (vi) estabelecimento de técnicas de medida de desempenho organizacional coerentes; (vii) um programa de comunicação efetiva; (viii) alinhamento do sistema de remunerações e de outras práticas de GRH com as metas e os objetivos da mudança.

Por comparação com esta análise da realidade das intervenções organizacionais em empresas americanas, ao nível dos aspetos gestionários apenas não podíamos controlar a dimensão vi), na medida em que não estava prevista qualquer mexida na avaliação de desempenho (o sistema, para além das acusações de subjetividade, assentava no processo de cotas: apenas $25 \%$ podiam ter classificação máxima, devendo ainda haver $25 \%$ de classificações negativas, pelo que o mês de Fevereiro, altura em que as avaliações eram comunicadas em sede de entrevista, era um período de máxima conflitualidade), embora os problemas mais gravosos tenham sido superados treinando as chefias no método de escuta ativa; bem como a dimensão viii), pois a Administração não abordaria qualquer hipótese de alteração do sistema de remunerações, situação que constituía um sério constrangimento, o qual deveríamos contornar com toda a perícia possível. Como se viria a verificar no decurso do programa de investigação/ação, o referido constrangimento seria superado a partir de uma adaptação à empresa da abordagem sociotécnica inspirada na teoria dos sistemas abertos, em que Katz e Kahn (1966), citados em Lopes e Reto (1983), identificaram nove características dos sistemas abertos que (e de que modo) podiam ser adaptadas ao modelo organizacional seguido: (i) entrada; (ii) transformação; (iii) saída; (iv) sistema como ciclo de eventos; (v) entropia negativa; (vi) mecanismo de retorno ou de feedback negativo e processos de codificação; (vii) estado firme e homeostase dinâmica; (viii) diferenciação; (ix) equifinalidade. 
Estas eram as nossas bases teóricas e perspetivas sistémicas de partida. Para se aceder a um sistema complexo, como é o caso das empresas atuais, é forçoso passar de uma visão analítica a uma visão sistémica, abordagem mais delicada do que possa parecer. Trata-se de uma visão verdadeiramente revolucionária no seio de uma cultura (latina): (i) que tem por hábito a procura de causas, em lugar de conexões; (ii) que procura interpretações baseadas na dimensão mais psicológica e individual do que inserida em circunstâncias existenciais e transpessoais; (iii) e que recorre a modelos particularistas em lugar de procurar uma abordagem de tipo universalista. A fim de conseguir estes propósitos, a centração na autonomia do ator organizacional pressupõe que se tenham em conta três preocupações em simultâneo: (i) a mudança desejável/ desejada; (ii) a liberdade de interação de todos os atores pertinentes envolvidos na cadeia de valor; (iii) acompanhamento dos atores implicados (ou afetados) na mudança. Evoca-se, aqui a visão sistemática da realidade organizacional, entretanto desenvolvida em profundidade por Bériot (2006), com base nos mesmos pressupostos do pensamento de M. Crozier, como "abordagem global da complexidade organizacional". Estas correspondem, entretanto, às linhas de orientação seguidas para lidar com o conflito institucional despoletado na sequência do relatório de diagnóstico, e que levaria à demissão do mais antigo dos Diretores Gerais e dos seus colaboradores mais diretos na fileira da produção

Era difícil de obter, entretanto, um comprometimento ativo da liderança organizacional no processo de mudança ( $1^{\mathrm{a}}$ dimensão) na medida em que parecia existir um conflito grave e fraturante, derivado da forma como tinha sido repartido o poder por dois diretores gerais, cerca de dois anos antes do início do Programa, e cujas repercussões desconhecíamos.

\section{DIAGNÓSTICO DE NECESSIDADES FORMATIVAS E FORMAÇÃO DO VÉRTICE ESTRATÉGICO - $1^{\text {a }}$ FASE}

$\mathrm{Na}$ I/A utilizaram-se diversos métodos de pesquisa (triangulação de dados). Mas o diagnóstico promove por si mesmo uma cultura de mudança e de avaliação contínua, oferecendo oportunidades para que os gestores adquiram novos hábitos e insights sobre aspetos disfuncionais ou padrões de comunicação desajustados. O diagnóstico é, assim, entendido como um processo formativo (Beer e Spector, 1993). 
De acordo com Spector e Beer (1994), os processos de TQM falhavam, nos EUA, em $75 \%$ dos casos. O envolvimento da gestão de topo é efetivamente crucial para contornar a resistência normal à mudança. É apenas a direção superior que possui as condições indispensáveis para poder enviar os sinais à organização sobre a prioridade da mudança, no dizer de Galpin (1996).

5.1. Diagnóstico de custos ocultos (com recurso a questionários, entrevistas, observação participante e análise documental): (i) absentismo (cálculo de custos indiretos); (ii) rotação externa; (iii) acidentes de trabalho e outras questões relevantes do âmbito da SHST (como o impacto dos pequenos acidentes de trabalho, precisamente aqueles que não são participados a entidades seguradoras, tendo-se chegado a valores de $1 \%$ da massa salarial total num estudo realizado); desperdícios; (iv) devoluções/reclamações.

5.2. Diagnóstico de conflitos, de motivação, de estrutura, de cultura e de liderança.

5.3. Diagnóstico de incidentes críticos e observação de postos de trabalho concretos.

5.4. Diagnóstico (de dicas e de queixumes) baseado em confidências: fase de expressão livre dos trabalhadores.

5.5. Diagnóstico de clima, afetado pelas anteriores estratégias de: (i) redução de pessoal; (ii) introdução da polivalência; (iii) gestão independente dos RH das Vendas e da Produção (ex.: férias no sector da produção em Julho, coincidindo com o pico das vendas).

5.6. Diagnóstico de comprometimento organizacional, com base numa garantia de transparência, tendo em conta os seguintes parâmetros: (i) informação; (ii) poder; (iii) recompensas; (iv) formação; (v) análise das congruências e consistência destes quatro pilares (da GERH).

5.7. Análise dos designados "custos de contexto" da atividade industrial em Portugal, nomeadamente, no domínio das relações laborais, pois a relação com os sindicatos era muito tensa: a título de incidente crítico, refira-se o facto de um colega da equipa do ISCTE, indicado para integrar a equipa de investigação/ ação, ter sido liminarmente vetado pela Administração, por no passado ter sido consultor sindical de uma estrutura filiada na CGTP.

5.8. Contextualização do conflito Vendas/Produção: esta considerava que as Vendas enviavam as melhores encomendas (grande série para a 
fábrica de Leiria, enquanto para as Vendas a pequena série era o futuro, assim a Produção fosse flexível).

5.9. Análise e superação das dificuldades na formação do vértice estratégico (é difícil um líder aceitar questionar-se). A liderança da Produção aos diversos níveis sentia-se injustiçada pelo relatório. Havia uma certa confusão entre diagnóstico para melhorar e auditoria interna (de cariz habitualmente punitivo), situação que conhecíamos mas que era impossível de contornar, sem podermos explanar longamente o contexto das reflexões sobre os factos que permitiam o nosso diagnóstico. O contexto de um relatório escrito e lido internamente, sem o nosso acompanhamento, causava-nos as maiores apreensões. Os conflitos são irresolúveis quando não se pode baixar à fase de problema, por ação de uma qualquer mediação. Corria-se o risco de o documento ser perspetivado como a tomada de partido pela liderança das Vendas.

\section{RELATÓRIO E DEVOLUÇÕES DE DADOS (A QUENTE): DIFICULDADES E POTENCIALIDADES.}

$\mathrm{O}$ relato dos factos que se iam descobrindo, se pudesse ter sido imediatamente partilhado, ajudaria a criar um sentido de urgência para a mudança associado a uma necessidade de uma mais baixa conflitualidade de interpretações ou de atribuição de responsabilidades internas. De outro modo seria mais difícil de obter um diálogo crítico construtivo, tal como viria a verificar-se. Como se verá com o desenrolar dos factos, esta dificuldade de devolução de dados de maneira faseada, viria a constituir o maior obstáculo ao desenvolvimento do Programa de Mudança Organizacional, para além de agravar de maneira irreversível a ausência de consenso ao nível da direção estratégica.

6.1. Questionamento (não havia no relatório uma atitude crítica) da estrutura bicéfala enquanto "analisador institucional". Havia cerca de dois anos que a Direção Geral da empresa, que detinha um histórico da Produção desde a fundação, fora forçada a partilhar a mesma com um especialista de Vendas. Esta era uma indicação de que o mundo mudara e que a prioridade passara a ser "produzir o que se vende " e não "vender o que se produz". Vale a pena referir, entretanto, que a situação era muito difícil de apreender pela complexidade gerada ao nível da estrutura de controlo superior, com uma liderança dotada de um forte crédito idiossincrático (Hollander, 1958), na Produção, e uma liderança construtivista (Walker e Lambert, 1995), nas Vendas. A saída do líder da 
produção, pouco tempo depois, viria a consolidar a perceção da estrutura de comando como estando mais próxima do senso comum.

6.2. Institucionalização da pesquisa de não conformidades baseada no princípio da "auditoria punitiva". O facto de as auditorias internas apontarem um dos dois setores (Vendas - Produção) como responsável por uma qualquer devolução, revelou-se fatal para a comunicação interna, até porque nunca revelava os aspetos subjacentes às falhas apontadas. $\mathrm{O}$ grupo das vendas tornou-se o inimigo interno da produção, impedindo esta de olhar para fora, vendo antes a concorrência como efetivamente o "inimigo". Os números apontavam, entretanto, para uma situação insustentável (produto vendido a um valor próximo dos $10 \%$ abaixo do preço de custo e, ainda assim, $10 \%$ acima do preço de mercado). Mas, com a bicefalia, os fatores de agravamento da situação de mercado tinham-se agravado todos, pela conflitualidade que tinham desencadeado.

6.3. Consequências em termos de relação intergrupos; dificuldades face à introdução do modelo de gestão pelas competências.

6.4. Envolvimento muito baixo dos trabalhadores.

6.5. Traçado um prognóstico positivo, tendo como pontos fortes a cultura fusionária (na medida em que podia ser potenciadora do trabalho em equipa) bem como a "autogestão clandestina", na medida em que seria reveladora de um elevado desejo de autonomia e de profissionalismo.

6.6. Outros aspetos a considerar, no respeitante à cultura dos dois principais grupos (vendas e produção): (i) a existência de uma Cultura (do grupo comercial) Ganhadora, Tranquila e Meritocrática; (ii) uma Cultura (do grupo fabril) Dominada, Defensiva e Coesa servida por uma liderança autoritária (refira-se o facto de se contar na fábrica que, durante as férias do diretor, a produtividade aumentava, devido ao estilo de liderança do subdiretor, com um perfil claramente relacional, em contraste com o tipo tecnocrático do diretor fabril, de acordo com os perfis definidos por Pitcher, 1997), que reforça as hipóteses de perda no confronto intergrupos; (iii) relatório final de diagnóstico/intervenção, apresentado por escrito (ou seja, a frio e impedindo, momentaneamente, o efeito de "escola corporativa", com a passagem à fase seguinte, a da formação dos líderes intermédios, como base reinterpretativa da empresa), por exigência da empresa, exacerba o conflito institucional.

6.7. Abordagem dos eventos que afetaram o clima interno e intervenção direta do Conselho de Administração para se criarem as 
condições de passagem à $2^{\mathrm{a}}$ fase. A própria solução encontrada, de optar por uma bicefalia organizacional, parecia não responder ao problema de fundo. A "solução" era, por isso, mais gravosa do que o sintoma. A liderança bicéfala, talvez arquitetada na sequência da divulgação da liderança japonesa do Grupo Matsushita (Pascale e Athos, 1981) estava mal arquitetada e pior implementada. Os autores consideravam o bem fundado de uma liderança complementar, do tipo familiar, com o pai e a mãe a entenderem-se na arte do governo da casa e não de uma liderança rival, como parecia existir no caso da Portucel Embalagem.

\section{FORMAÇÃO DOS RESPONSÁVEIS DE GESTÃo INTERMÉDIA (HIPÓTESE DE LANÇAMENTO DE UM CÍRCULO DE GESTÃO OU DE PILOTAGEM PARA ULTRAPASSAR O IMPASSE DA $1^{\text {a }}$ FASE): INÍCIO DA $2^{\text {a }}$ FASE}

A questão do papel central da gestão intermédia é relativamente recente e ainda insuficientemente investigada. King, Fowler e Zeithaml (2002) afirmam que os gerentes de nível intermediário representam o elo fundamental na articulação e na participação de toda a estrutura. Através de uma investigação recente de Dias, Lopes e Parreira (2011) foi igualmente possível demonstrar o bem fundado do envolvimento prioritário das chefias intermédias e de lançar com elas um programa de liderança participativa. A anuência e a comunicação ajudam a gerar concordância a respeito das principais fontes de vantagem competitiva da empresa, a concentrar os esforços da organização e a aumentar a probabilidade de uma implementação ser bem-sucedida" como referem King, Fowler \& Zeithaml (2002).

7.1. Razão de ser desta decisão: hipótese da hipertrofia da estrutura ser resultante da gestão das devoluções. A hipertrofia da estrutura resulta das "duas direções gerais" sentirem-se como duas empresas concorrentes que, embora vivendo o dia-a-dia profissional nos mesmos locais, fazendo reuniões conjuntas e partilhando as mesmas estruturas de apoio, a empresa vivia um choque de culturas, como o inverso de uma fusão, com todas as consequências ao nível da produtividade, em queda constante. Quanto à gestão das devoluções, era difícil aos responsáveis da Produção darem-se conta das exigências de flexibilidade da economia dos anos 80, em que os pequenos "cartonageiros", por exemplo, respondiam com eficácia às necessidades dos clientes, com melhores preços e melhor adaptação dos prazos de entrega do que as grandes estruturas, na linha do 
que viria a constatar Fukuyama (2000) quando escreveu que as grandes empresas hierarquizadas foram nos anos 80 vítimas de competidores mais pequenos, mais rápidos e mais ágeis.

7.2. Análise das reclamações/devoluções e consequências ao nível cognitivo: o conflito intergrupos impede o conhecimento do outro enquanto ator organizacional.

7.3. Desenho do ciclo do produto e hipótese de lançamento de uma estrutura virtual.

7.4. Reflexo da divisão entre grupos condiciona a autoformação em ciclo do produto.

7.5 Levantamento de problemas, escolha de um problema simples e que envolva toda a estrutura e tratamento imediato dos problemas relativos à informática.

7.6. Formação em avaliação de desempenho: a liderança eficaz e a questão da designada de "escuta ativa" (método já referido).

7.7. Mudança institucional na sequência da unificação da DireçãoGeral sob a responsabilidade do Diretor-geral de Vendas (um novo líder, mais dialogante, saído do laboratório de qualidade, assume a gestão da Fábrica, mantendo-se o Diretor de Vendas Sul).

7.8. Análise das condições que afetaram a decisão de passagem à $2^{\mathrm{a}}$ fase e releitura do "fracasso".

7.9. A descoberta da importância determinante da liderança intermédia, como instância intermediária, na elaboração e na "venda" do projeto às restantes instâncias organizacionais. As teorias da liderança em que nos podíamos apoiar, nesse período do final dos anos 80 , ainda não reconheciam a liderança intermédia (o tronco hierárquico, na designação de H. Mintzberg) como uma entidade organizacional com um papel autónomo, falando-se preferencialmente como se de uma instância de retransmissão das mensagens do topo se tratasse. O que viria a verificarse, no decurso do processo de mudança é que esta instância se sentiu atraída pela oportunidade de alargar a sua área de influência e de poder institucional, pela existência do Programa. Esta terá sido uma das principais surpresas do comportamento organizacional ao nível da estrutura de poder. 


\section{FORMAÇÃO CONTÍNUA DA LIDERANÇA INTERMÉDIA (CÍRCULO DE PILOTAGEM) E DO VÉRTICE ESTRATÉGICO (CÍRCULO DE ESTRATÉGIA)}

8.1. Composição dos dois órgãos. A primeira reunião das chefias intermédias foi marcada, pelos dois diretores gerais (ainda estavam ambos em funções, embora logo de seguida o DG de Produção tenha sido afastado), para os primeiros dias de Janeiro de 1989. Foram convocados cinco quadros dirigentes do sector das Vendas e oito da Produção, ou seja a totalidade dos responsáveis com funções de chefia, que geriam direta ou indiretamente unidades internas enquadradas na cadeia de criação de valor. $\mathrm{O}$ que se passava, entretanto, era que a estrutura, como acontece habitualmente, refletia uma evolução histórica e não uma linha de coerência. Mas em lugar de se proceder a uma reengenharia da estrutura, como então começava a ser moda fazer-se, organizou-se este órgão coletivo como uma instância dirigente onde todos possuíam estatuto de igualdade. É curioso que se tratava de um verdadeiro desafio de fusão de duas culturas radicalmente diferentes e que antes se defendiam mutuamente de uma qualquer absorção hegemónica.

O quadro de engenharia mais qualificado da estrutura de Produção pediu automaticamente escusa de participar na reunião, argumentando com o carácter voluntário da mesma, realçado na convocatória. A sua maior surpresa seria entretanto a de constatar que ninguém mais o acompanhou naquela sua postura de alheamento (tratava-se do único licenciado em engenharia mecânica, a trabalhar no meio fabril, embora não tivesse funções hierárquicas atribuídas, sendo adjunto da direção da fábrica). $\mathrm{O}$ fenómeno configurava eventualmente uma tentativa de influência de tipo intergrupos em que o ausente representaria a maioria como na experiência de $\mathrm{S}$. Asch e os que ficaram se assumiram como grupo minoritário, consistente e ativo, com capacidade de liderar uma mudança efetiva da cultura organizacional fragmentada, na brilhante definição de Martin (1992), em ordem à sua unificação como cultura de marketing (Cravens e Piercy, 1995). Os autores, em estudos de caso semelhantes a este, destacaram sete tendências de fundo nas empresas orientadas para a qualidade e para o mercado (propósito semelhante ao nosso): (1) redução da hierarquia; (2) pequenas unidades internas de negócio; (3) equipas inovadoras de projeto; (4) reengenharia da produção - orientação por processos; (5) orientação para a internacionalização do negócio; (6) segmentação e gestão de clientes; (7) desenvolvimento de uma organização aprendente para o desenvolvimento contínuo de competências. 
O grupo decidiu, pois, continuar e reunir todas as terças-feiras de manhã, durante três horas, para que todos se ficassem a conhecer e expusessem os problemas das respetivas divisões de trabalho.

Quanto à liderança de topo (círculo de estratégia), decidiu-se efetuar uma reunião mensal, com os dois responsáveis (Vendas e Fábrica) e com o novo Diretor-geral (conjunto), a fim de apreciar o trabalho do grupo de pilotagem (ou de gestão) e aprovar propostas de reestruturação de procedimentos para os quais este não tivesse poder/delegação de alteração. Importa ter presente as recomendações de Ancona, Malone, Orlikowski \& Senge (2007) acerca da liderança incompleta (humildade para estimular o talento e reconhecê-lo onde quer que este se revele). Entretanto a equipa de liderança, segundo o mesmo estudo, deveria reservar-se para a função de criar sentido, desenvolver um profundo espírito de bom relacionamento, inspirar uma visão partilhada e promover a inventividade. Estas quatro competências constituíram efetivamente o clima da convocatória e das reuniões conjuntas entre os grupos de liderança estratégica e de pilotagem.

8.2. Dotar a organização de uma cultura de liderança institucional. A nível da estratégia propriamente dita, como dimensão organizacional, poderá facilmente constatar-se que a liderança de topo gasta com frequência a maior parte do seu tempo na gestão das tarefas correntes, descurando-se as tarefas da criação de sentido e da definição dos grandes objetivos em função das alterações do meio envolvente. A organização de um grupo de gestão intermédia, designado de "círculo de pilotagem", permitiria que a gestão corrente fosse exercida por este órgão coletivo, que possuía virtualidades para observar a realidade interna a 360 graus, libertando, por sua vez o topo para as funções mais estritamente estratégicas. Recorde-se as reflexões de Bennis e Nanus (1985), uma obra a todos os títulos essencial, ao alertarem que: as empresas estão habitualmente sobre-geridas e sub-lideradas. Complementando as duas posições aqui retratadas (Ancona et al, 2007, bem como a de Bennis e Nanus, 1985) seríamos forçados a dizer que a visão orientadora de futuro (se ela é indispensável) não pode ser conseguida pelo líder sem a participação assumida dos colaboradores e dos parceiros intervenientes na cadeia de valor da empresa, dada a sua incompletude.

8.3. Apenas uma estrutura deste tipo parece suscetível de criar as condições para se ultrapassar o mito da liderança completa (Ancona, Malone, Orlikowski \& Senge, 2007). 
8.4. Elevação (virtual) das chefias intermédias a órgão coletivo de gestão, como referido em Lopes, Dias e Parreira (2009), com importância determinante na reelaboração do projeto organizacional, face à que é atribuída à liderança de topo, (o projeto organizacional seria efetivamente reelaborado a este nível e não pela gestão de topo).

8.5. Formação da liderança intermédia, em ciclo do produto/serviço e potencial deste método formativo para a criação de um espírito de grupo e de equipa. Apesar da proximidade, e da convicção dos participantes de que todos sabiam exatamente o que cada qual fazia, o certo é que esta formação em ciclo do produto se revelou uma caixa de surpresas. Os problemas ditos de interface, de que ninguém se ocupava, detetados por cada responsável contavam-se por dezenas com um impacto fortíssimo na produtividade global.

8.6. Possibilidade real de fazer emergir "objetivos supra-ordenados", a partir da tomada de consciência, por parte do grupo da Produção, da relevância da noção de serviço ao cliente como base da colaboração intergrupos.

8.7. Ritual de exploração dos êxitos (caso das vicissitudes que envolveram a procura de soluções para o problema da paletização, em que a experimentação da tomada de consciência de que era um serviço, e não a faturação de um produto ao cliente, foi determinante para a criação de um "objetivo supra-ordenado" para toda a empresa).

8.8. Criação de uma dinâmica de comunicação identitária simbolizada pela criação de uma marca interna, já amplamente tratada.

8.9. Programa de implementação da descentralização (princípio da subsidiariedade), com a liderança intermédia (coletivamente entendida) a passar de uma autonomia de 2.000 contos (10.000 EUROS) para 35.000 contos (175.000 EUROS).

8.10. Gestão do envolvimento/comprometimento dos colaboradores (os 4 pilares: formação, informação, poder, recompensas).

8.11. Razão pela qual se tinha fracassado no processo de formação do topo estratégico e porque só nesse momento se podia falar da questão de completar a $1^{\text {a }}$ fase do programa inicialmente planificado e acordado. $\mathrm{O}$ funcionamento do círculo de estratégia não parecia ter sido possível de conseguir enquanto as chefias intermédias não começassem a provar que eram perfeitamente capazes de operar no dia-a-dia sem qualquer ajuda, dando assim espaço para a operacionalização das duas funções da liderança: a gestão e a condução estratégica. 


\section{FORMAÇÃO DE CHEFIAS DIRETAS (EM CASCATA) - $3^{\text {a }}$ FASE}

A formação em técnicas de escuta ativa, das chefias intermédias (sobretudo das chefias diretas), revelaria todas as suas potencialidades de alinhamento para cima e para baixo no sentido da emergência de uma liderança participativa transversal a toda a estrutura da empresa.

Este trabalho com as chefias intermédias revelar-se ia de uma importância capital para a melhoria do clima e da satisfação dos trabalhadores, profundamente agastados com o sistema de cotas da Avaliação de Desempenho. O facto de as chefias saberem escutar os seus colaboradores foi igualmente determinante para consolidar a liderança da Comissão de Trabalhadores e torná-la num parceiro ativo da gestão, quando até então esta se assumia como mera correia de transmissão dos sindicatos maioritários na indústria de "Artes Gráficas e de Transformação do Papel”.

9.1. Caracterização da resistência das chefias: teoria $X$, preocupação com o status, ceticismo face ao empenhamento do topo, preocupação com a igualdade, responsabilidade do negócio (não corresponsabilidade).

9.2. Vencer a resistência das chefias (saber dar uma explicação antes de formular uma ordem; saber obter o comprometimento afetivo dos colaboradores; aprender a delegar; utilização das técnicas de criação de um espírito de equipa nos grupos de trabalho). A resistência não é mais do que a defesa legítima da preservação da capacidade de influência e da preservação dos legítimos interesses pessoais, afetados pelas mudanças de contexto interno e externo. Quando o processo se torna participado e elaborado coletivamente, a resistência metamorfoseia-se em propostas contrastadas e criativas do ponto de vista da resolução concreta de problemas.

9.3. Os dirigentes formavam os chefes de equipa em ciclo do produto, tal como se tinha feito entre pares, no grupo de dirigentes intermédios.

9.4. Superação de dificuldades pessoais: são, ainda hoje, raros os estudos empíricos sobre a gestão dos grupos de trabalho pelas designadas chefias diretas. $\mathrm{Na}$ altura do estudo apenas dispúnhamos de referências esparsas à dificuldade de reconversão de chefes em animadores de equipas semiautónomas. Foram programados dois workshops com os 43 chefes diretos, de três horas cada, para os informar das ações de formação a desenvolver no âmbito dos respetivos dirigentes intermédios. Pretendia- 
se ajudá-los a confrontar a sua representação social de chefia nesta empresa concreta com uma representação adequada à mudança a criar nas suas mentes. Foi possível elencar quatro dimensões principais interconectadas: as reuniões semanais de equipa (apoiadas em sistema de coaching, pela equipa facilitadora, quando chegasse a sua vez) seriam animadas por eles; de chefes passariam, agora, a ser animadores que ouvem e dariam a palavra, sem a tomarem para si; o desafio a enfrentar era o de inventariar problemas individuais e coletivos a resolver por etapas a partir do método PDCA; e esperava-se que o papel de animador passasse do espaço de reunião para o "chão da fábrica" (Autissier e Vandengeon-Derumez, 2007). Este trabalho permite-nos confrontar as posições dos autores com a nossa I/A. Os autores assinalam, a este propósito, que encontraram quatro perfis de chefes diretos, em função dos parâmetros ativo/passivo e negativo/positivo: negociadores (estes posicionados no eixo ativo/positivo), legitimistas, contestatários e indiferentes. Destes, apenas os primeiros seriam capazes e desenvolver uma liderança participativa. Os autores dizem ainda que só dois em 15 chefias das duas empresas estudadas se encaixavam nesse perfil. Ora, sem escolher ninguém em particular, era possível ter, na Portucel Embalagem, ao fim de dois anos de trabalho, 15 chefes a trabalhar por equipa (a totalidade dos consultados para o efeito).

9.5. O processo permitiu a dignificação das chefias face aos seus colaboradores de base.

9.6. Conteúdos concretos da formação (resolução de problemas - por etapas, inspirando-nos no modelo de implementação dos círculos de qualidade).

9.7. Opção pelas chefias formais para liderar os grupos.

9.8. Utilização da noção de "dissonância cognitiva" (com a introdução do método da escuta ativa, as chefias eram obrigadas a ouvir antes de reagir e a solicitar a opinião do colaborador antes da tomada de decisão, distanciando-se da perspetiva tradicional, como desenvolvido por Eden, 1990; 1992) para se conseguir a mudança da atitude das chefias diretas no processo quotidiano da organização do trabalho (evolução da ideia de grupo para a de equipa).

9.9. Análise do processo de mudança a partir do desenho de um modelo de formação profissional contínua, concebido de acordo com os seis princípios da andragogia (distinção entre ações de formação centradas no sujeito e aprendizagem organizacional): centralidade do adulto aprendente; fornecedor/facilitador de formação; processo 
formativo conduzido de acordo pelo sistema cliente, com respeito pelo primado da procura e não da oferta; trabalhar a noção de necessidade de formação e traduzi-la em desejo de aprender (para evitar a indesejabilidade da formação, esta foi inserida no processo normal de trabalho em equipa, em que a reunião se transforma no cerne do processo formativo); produção de indicadores de eficácia e de eficiência formativa; transformação do ambiente interno, transformando a organização em instituição aprendente.

$\mathrm{O}$ modelo pretende situar as categorias centrais de "Adulto em Formação" em contraponto com a de "Organização que Aprende" (LO) através de uma abordagem sistémica: entrada, transformação, saída e mecanismo de feed-back. Atente-se que para que se verifique uma articulação virtuosa entre as duas instâncias do modelo é necessário que o Adulto se transforme em categoria nuclear influenciando diretamente os dois subsistemas que lhe estão associados e, simultaneamente, deseje formar-se (não basta a necessidade) e a aprendizagem, a qual quando devidamente auditada com base num conjunto de 24 indicadores de eficácia e de eficiência deverá poder criar condições de sustentabilidade, gerando uma LO. A aprendizagem individual, entre adulto aprendente e formador, exige, por sua vez, que se estabeleça entre ambos uma relação minimamente empática, que aquele esteja em condições de apreender os conteúdos formativos e que o formador seja eficaz na sistematização do conhecimento.

No âmbito do processo descrito, a organização de perfil burocráticomecânico (induzido pela cultura nacional, entendida segundo a abordagem de Hofstede) transformar-se-ia numa rede de micro-unidades, tendendo a controlar todo o ciclo de criação de valor, bem como a transformar as organizações fornecedoras em parcerias.

\section{FORMAÇÃO DAS EQUIPAS DE TRABALHO E PRINCÍPIO DA INVERSÃ̃ DA PIRÂMIDE - ADOÇÃO DA ESTRUTURA EM REDE (CÍRCULOS DE QUALIDADE) - $4^{\mathrm{a}}$ FASE}

A eficácia formativa pode parecer uma questão simples, mas ela tem todos os ingredientes para poder falhar. Efetivamente a aprendizagem de tipo andragógico implica uma prévia desaprendizagem daquilo que o adulto sabe (ou, melhor dito, do que julga saber), através da elaboração do seu mapa cognitivo (Weick, 2001) a fim de se destrinçar o que sabe 
efetivamente daquilo em que passa a ter dúvidas, método, esse, que, quando elaborado em grupo, se revela crucial para que a relação empática com o formador funcione. Só depois a transmissão de conhecimentos, por via interrogativa/demonstrativa se poderá processar. Como atrás se mostrou, a formação equivale a um processo de mudança profunda.

10.1. Clareza da missão da empresa na mente de todos os funcionários e rede de parceiros diretos onde antes havia relações de subcontratação.

Adiante especifica-se que esta relação de parceria é tanto mais importante quanto o fator cooperação entre PME's é sistematicamente classificado como sendo o pior desempenho do país, e da OCDE, no que concerne o indicador global inovação, de acordo com os dados da COTEC.

10.2. Vencer a resistência à mudança dos funcionários (o que pressupõe o desenvolvimento de cinco práticas estratégicas determinantes de Gestão de Pessoas: estabilidade de vínculo, formação, comunicação, trabalho em equipa e empowerment);

10.3. Liderança centrada no apoio personalizado, na escuta ativa e na comunicação persuasiva junto dos sectores de trabalho;

10.4. Sistema de avaliação de desempenho credível (o que pressupõe objetivos individuais e de equipa, compatíveis e com características SMART);

10.5. Trabalho em equipa/método de resolução de problemas (formação/sensibilização ao tema).

Lucas (2012:373), com base na ideia de "pensamento reflexivo" de J. Dewey, propõe um método de resolução de problemas em cinco etapas: (a) correta definição do problema; (b) análise exaustiva do mesmo; (c) definição cuidada dos critérios para a resolução do problema; (d) inventário aturado das potenciais soluções; (e) seleção criteriosa de uma alternativa para poder ser testada. Face a outros modelos de resolução de problemas, este tem o mérito de se basear num suporte académico robusto

10.6. Transferência de conhecimentos;

10.7. Definição do poder de proposta para passagem da lealdade à voz - como no caso paradigmático dos equipamentos de monta-cargas;

10.8. Conceitos de A. Hirschman (Sabino \& Lopes, 2012; Sabino Lopes \& Nogueira, 2015);

10.8.1. Reduziu-se o espaço da estratégia (positiva, mas passiva) da lealdade organizacional, do tipo "eles não percebem" (apesar de tudo positiva), para se passar à participação definida como estratégia de voz e mais tarde como de voz individual, através da estratégia comunicacional 
da "escuta ativa", por parte das chefias, por ocasião da prática de avaliação de desempenho por quotas (4 tipos, desde o muito bom ao muito mau);

10.8.2. A voz coletiva, correspondente à capacidade de decisão (experimentações e recompensas), foi apresentada como a garantia de que se estava a trabalhar no sentido de haver sempre um espaço de criação de condições de liberdade e de participação efetiva no processo de organização do trabalho, retirando-se em simultâneo espaço à estratégia de negligência anteriormente dominante.

10.9. Os novos valores ligados ao TQM que emergem do processo encetado foram, nomeadamente, a recolha sistemática dos requisitos e dos constrangimentos de armazenagem dos clientes (toda a empresa estava a iniciar um processo de transição da organização do trabalho baseada no produto para uma organização baseada na noção de serviço ao cliente, e no primado deste), uma maior atenção por parte das equipas (CD's) às potencialidades dos contratos com os fornecedores (camionistas privados e equipa de desenhadores, entre outros), a constituição das equipas plurifuncionais para a resolução de problemas globais (englobando gente de todos os departamentos e conhecidos na literatura da especialidade como "grupos de progresso"), o método científico (formulação de hipóteses verificáveis a partir de problemas e de teorias adequadas) na abordagem às causas mais prováveis ou à solução dos problemas e a operacionalização da "inteligência coletiva" da organização, promotora de uma racionalidade que designaríamos, entretanto, de emergente. Progressivamente era toda a empresa que se procurava organizar em grupos de desenvolvimento, em lugar de resistir à gestão participativa como seria de esperar, de acordo com o senso comum que vê no espírito sindical um obstáculo à motivação para o comprometimento organizacional.

Atente-se no desenho de uma pirâmide hierárquica típica da burocracia mecânica, dominante na cultura portuguesa, com as suas seis diferentes forças/lógicas (dominância da lógica integradora).

A burocracia mecânica (BM) era, em termos gerias, a configuração da estrutura existente na empresa, à partida. Importa acrescentar que a "tecnoestrutura" (instância dominante das burocracias mecânicas tayloristas) era neste caso relativamente embrionária, pelo que não aparece emancipada no desenho proposto, tal como não existia uma estrutura de "apoio" propriamente desenvolvida mas antes parcialmente 
integrada no "tronco hierárquico", este sim muito expressivo. A dimensão "tronco hierárquico" era a verdadeira dimensão dominante em termos de poder.

Para uma melhor compreensão do desenho encontrado e das diferenças face a uma BM típica, apresentam-se as componentes de toda a estrutura organizacional, as quais são, de acordo com Mintzberg (1982, 1986), as seguintes: (i) Cultura - engloba valores, crenças, tradições, heróis ou sagas, que distinguem as diferentes organizações; (ii) Vértice Estratégico - constituído pela gestão de topo e tem como objetivo proporcionar a todos os colaboradores as condições necessárias para que a organização possa atingir os seus objetivos; (iii) Tecnoestrutura constituída por analistas do trabalho e planeamento e por responsáveis de organização e métodos, os quais visam obter a estandardização dos processos; (iv)Tronco Hierárquico - formado pela direção intermédia, que tem como tarefa principal fazer a ligação entre o vértice estratégico e o centro operacional, garantindo o alinhamento com a cultura e o projeto da organização; (v) Núcleo de Apoio Logístico - instância que agrega pessoas que têm a seu cargo os serviços administrativos, jurídicos, de relações públicas e laborais, entre outros; (vi) Centro Operacional instância de execução dos trabalhos de base relacionados com a produção de bens/serviços, a distribuição e a venda de produtos. A estrutura tipo encontrada comporta dificuldades específicas de comunicação e apenas pode funcionar quando submetida a uma direção muito rigorosa de submissão estrita às normativas da tecnoestrutura.

A cultura portuguesa reinterpreta, efetivamente, este tipo de estrutura e transforma-a, mais propriamente numa organização dominada pela perspetiva da unidade de comando, de tipo fayolista, onde a tecnoestrutura aparece atrofiada, face a um tronco hierárquico hipertrofiado. É assim que em lugar de 8 áreas de direção previstas como máximo pelo taylorismo, encontramos 14 diretores intermédios, na empresa em estudo. Assim se multiplicam as instâncias de comando, coordenação e controlo, a partir do tronco hierárquico, em lugar de distribuir essas funções pelas duas subestruturas: tronco hierárquico e tecnoestrutura. Perde-se em racionalidade e ganha-se em coordenação.

O processo de inversão da pirâmide hierárquica foi conseguido através de um programa muito complexo de "mudança e desenvolvimento organizacional." Este processo parece só ter sido possível porque existia um grupo de facilitadores externos, liderado por investigadores de elevado estatuto (Professores da Universidade). Na sua ausência, mesmo 
que o saber tivesse sido transmitido aos estagiários, o efeito de inversão e de gestão participativa viria a dissipar-se, pouco tempo depois, conduzindo à saída da técnica que tinha ficado vinculada à empresa após o estágio. A explicação para o facto não é fácil de encontrar. Sabemos por Bollinger e Hofstede (1987) que em Portugal as pessoas têm tendência a focar-se no desempenho dos superiores e não no seu, ao contrário do que se passa na Europa germânico-nórdica, levando os dirigentes a desconfiar dos modelos participativos. Por sua vez, só concentrando-se no que sabem fazer bem (o seu domínio de competência) os trabalhadores podem rentabilizar o processo participativo $\mathrm{e}$ aceder à autonomia. A operacionalização deste princípio participativo traduz-se numa obrigação mútua de propor soluções para cima (competência deliberativa) e de aceitação (competência decisória), o que leva a uma dissociação do primado da pirâmide hierárquica tão cara à nossa cultura. Quando a participação não é alimentada do exterior do processo de liderança tradicional hierárquico, ela parece tender para o enfraquecimento.

\section{DADOS E DISCUSSÃO DE RESULTADOS}

11.1. Processo de criação de sentido da Investigação/Ação desenvolvida, levando o líder a redesenhar a estrutura delegativa da fábrica.

De acordo com Weick (1998: 82), seriam sete as propriedades do "sensemaking" ou "criação de sentido" (identidade, retrospeção, primado da ação, atividade social, evento em curso, indícios e plausibilidade).

11.2. Resolução do conflito intergrupos: vendas versus produção.

11.3. Produção de indicadores: trabalho inútil, desperdício, política de transportes, energia/vapor, relação com os clientes, subcontratação na base das redes de parcerias.

11.4. Estrutura (o orçamento depende das decisões autónomas e responsáveis das chefias intermédias, operando-se, assim, a inversão da pirâmide hierárquica).

11.5. Liderança (a partir da noção de escuta ativa - punir versus aconselhar).

11.6. Motivação (controlar versus participar).

11.7. Cultura de qualidade baseada nos valores de Quinn e Cameron (1983). 
11.7.1. Controlo do Processo Interno/Filosofia de Just-in-Time (JIT) com vista à redução dos desperdícios (casos emblemáticos da redução de tempo na substituição das bobines de papel ou da carga de camiões);

11.7.2. Relações Humanas/Autonomia de Equipa (repartição de tarefas coletivamente assumida - caso das agrafadeiras) e controlo da qualidade pelos próprios operadores (jidoka, em japonês, podendo estes parar o processo produtivo se e quando detetam erros);

11.7.3. Objetivos/Serviço centrado no primado do cliente (todo o processo produtivo passaria a ser desenhado como um ciclo que começa na encomenda e termina na aceitação da carga);

11.7.4. Inovação/Criatividade (kaizen ou princípio da melhoria contínua) dos grupos, estando 15 destes a funcionar, regularmente, ao fim de dois anos e meio.

No âmbito do processo participativo que pretendíamos implementar de maneira durável, tratava-se, ainda, de desmontar os diversos "mitos" omnipresentes no processo de gestão da criatividade empresarial. Estes mitos tinham sido, entretanto, identificados por Amabile (1983): (i) a criatividade seria uma função específica da Investigação e Desenvolvimento (I/D) e não da base produtiva da organização; (ii) a pressão do tempo, e não a participação e o consenso a partir do trabalho em equipa, seria o fator que determinaria a emergência da criatividade; (iii) o medo, associado à criação de ambientes de incerteza, estaria na origem das forças que estimulam a criatividade; (iv) o comprometimento calculativo/instrumental (reportado ao sistema de remunerações e de carreiras) seria o motor da atitude propiciadora da criatividade; (v) a concorrência interna entre departamentos, equipas e sujeitos (uma noção derivada da organização como "mercado" proposto por Hofstede para caracterizar a cultura anglo-saxónica), seria a base do estímulo da criatividade; (vi) uma organização eficiente e atenta aos custos seria uma verdadeira organização criativa. Termina dizendo que a criatividade é sobretudo função da motivação intrínseca da pessoa talentosa e criativa, quando esta se encontra devidamente formada e dotada de um conhecimento especializado. Para a autora, os resultados empíricos dos estudos conduzidos nos EUA têm mostrado que, quando a participação e o trabalho em equipa foram devidamente operacionalizados, as pessoas revelaram-se criativas. Em trabalhos mais recentes, Amabile e Kramer $(2011 ; 2012)$ insistem que a questão da criatividade das pessoas se deve ao que designaríamos como uma liderança de proximidade e que proporcione uma visão holística do negócio: (i) definir claramente 
objetivos e finalidades; (ii) desenvolver a autonomia; (iii) proporcionar os recursos adequados; (iv) ser razoável na atribuição do tempo; (v) assegurar a ajuda necessária; (vi) proporcionar uma aprendizagem a partir dos próprios erros; (vii) apoiar inequivocamente os pequenos passos conseguidos, como forma de consolidar nas pessoas o sentido da autoeficácia.

11.8. Adoção de um sistema de formação profissional contínua, on job e JIT:

11.8.1. Promoção do princípio do primado da circulação do saber;

11.8.2. Reelaboração constante dos mapas cognitivos dos grupos (método andragógico);

11.8.3. Promoção da filosofia da L.O. (transformação da aprendizagem individual em aprendizagem organizacional) em toda a empresa, à medida que era possível lançar novos grupos de trabalho com recurso à filosofia de equipa.

Garvin (1993) queixa-se dos diversos teóricos e das suas propostas frouxas de implementação das L.O., contrapropondo a sua própria fórmula definida como criar/adquirir/transferir: (i) conceção e montagem de um processo operativo baseado na resolução sistemática de problemas; (ii) uma experimentação de novas abordagens; (iii) uma aprendizagem a partir das próprias experiências e dos ensinamentos do passado; (iv) confrontar a aprendizagem própria com as experiências e os sucessos dos outros; (v) disseminação do conhecimento através da organização. Pensamos que neste caso foi possível observar todas estas cinco características de um processo de aprendizagem organizacional, em linha com a proposta de D. Garvin (teórico e empresário de sucesso).

11.8.4. Gratuidade da formação (prescindindo-se, concretamente da formação financiada), pois esta passou a ser essencialmente on job (sob a forma de reuniões de trabalho de resolução de problemas) e ministrada apenas a partir de recursos internos.

11.9. Lucros, no final de 1990: cerca de 50 mil contos (recorde-se que o ponto de partida, dois anos antes, era de cerca de 700 mil contos de prejuízo), com um investimento total de seis mil contos pagos à estrutura universitária (ISCTE) que procedera à designação da equipa que desenvolveu esta I/A.

Os resultados foram, porém, sobretudo de tipo intangível, porquanto, no ano seguinte começou a ser desenhada a certificação pelas normas ISO 9001 (a mais geral, pois envolve a conformidade de um processo, da fase 
de projeto ao pós-venda), realidade anteriormente considerada impossível. Foi ainda uma das primeiras empresas portuguesas a conseguir aquela certificação.

\section{CONCLUSÃO}

A investigação/ação permitiu verificar que:

1. A qualidade é mais barata (ao reduzir custos substanciais) do que o trabalho pouco exigente.

2. Comprovou-se a tese de que terá sido suficiente a escolha de um só problema central para ser resolvido (a recuperação das paletes, abandonadas no armazém dos clientes), para que a mudança organizacional conduzisse a empresa na senda do novo paradigma da "era dos tecno-serviços" e do "paradigma colaborativo" envolvendo clientes internos e externos (Rouquet, Reniou e Goudarzi, 2013). Weick (1998) e Weick e Quinn (1999), que a este respeito invocam uma soma considerável de estudos dos anos 80 e 90, defendem que não se deve nem, de facto, se pode resolver mais do que um problema de cada vez. É uma das consequências do princípio da "ação local" para conseguir "pensar o global".

3. Não só se criaram postos de trabalho novos, em áreas afins da cadeia de valor (reparação de paletes) como se poderiam ter criado diversos lugares de técnicos de facilitação interna (da área de GRH), para animação de grupos e de "agentes de interface").

4. A mudança profunda foi possível e ela garantiu a passagem a uma fase superior de mudança contínua.

5. Os trabalhadores envolveram-se graças à formação, às ferramentas para a qualidade e à atenção permanente às suas ideias.

6. Tomou-se consciência de que os problemas (quando analisados sistematicamente à luz dos 5 M's) ultrapassavam as funções e as fronteiras organizacionais tradicionais. Este modelo permite a identificação da origem do problema pela análise dos designados 5M's, ou seja, trabalhando de acordo com o diagrama de espinha de peixe ou de Ishikawa: (i) matérias-primas incorporadas; (ii) materiais ou Equipamentos; (iii) meio envolvente; (iv) mão-de-obra; (v) métodos de trabalho.

7. O envolvimento do topo da organização, embora nunca tenha sido entusiástico, revelou-se fundamental para o arranque do processo, porventura, porque o modelo de intervenção, desenhado e seguido, não 
previa uma comunicação regular com o administrador delegado para a área de embalagem, a partir da passagem do programa para o interior da fábrica, deixaram de se realizar reuniões de informação na sede da Portucel Embalagem, e esse afastamento não permitiu informar corretamente o topo da organização bem como explorar os primeiros êxitos.

8. De pior das unidades do ramo Embalagem, esta fábrica onde decorreu a experiência de mudança tornou-se a melhor das fábricas do grupo, dois anos depois do início da I/A.

9. Tornou-se possível a passagem à fase da certificação da qualidade pelas normas ISO a partir do $3^{\circ}$ ano do início formal deste trabalho de promoção da mudança (1991).

10. Sustentabilidade da mudança organizacional contínua.

É interessante comparar os nossos resultados com o estudo conduzido pela American Productivity Quality Center (APCQ) nos EUA, de que se falou acima, a fim de que possa ser devidamente apreciada a amplitude da mudança conseguida, sem qualquer investimento, outro, que não o efetuado no processo formativo.

Retomando os termos da reflexão prévia, é possível elaborar uma síntese dos fatores de sucesso conseguido. No caso Portucel Embalagem foi possível tirar partido de alguns pequenos trunfos como: o envolvimento mínimo do Conselho de Administração, mesmo se o sistema de liderança estava muito longe de se envolver; a mudança de cultura arduamente conseguida, mesmo em presença de um descrédito generalizado de uma parte das chefias intermédias; expectativa positiva dos trabalhadores, apesar da desconfiança inicial; produção de indicadores de medida, apesar do desleixo do estagiário selecionado para o efeito; tudo isto conseguido apesar de uma impossibilidade real de alinhar a avaliação de desempenho com a gestão estratégica de Recursos Humanos. O grande trunfo em que todo o Programa de Mudança assentou foi, efetivamente, o da comunicação extremamente cuidada, como se mostrou. A organização passaria a ser o que esta comunicava, como defende, a partir dos anos 90, a designada "Escola de Montréal" (Grosjean e Bonneville, 2011), com a ideia central de "organização na comunicação".

Esta sustentabilidade foi conseguida em termos de:

10.1. Conteúdo (objetivos, mercados, produtos, metas e sua avaliação); 
10.2. Processos (formulação e implementação da mudança e sua calendarização);

10.3. Projeto organizacional gerado, desenvolvido e suportado no consenso da liderança intermédia, numa das primeiras experiências de I/A, a tê-lo perspetivado, a nível global, tanto quanto podemos saber.

Como atrás se referiu, na ausência de um consenso da alta direção, foi possível desenvolver um projeto organizacional ao nível intermédio, demonstrando a existência e a potenciação dos conhecimentos destes recursos inimitáveis, porque tácitos (Barney e Wright, 1998), como sendo a base da sustentabilidade das organizações, ao invés dos pressupostos da generalidade das teorias da liderança. Estas apenas lhe conferem o lugar de elo de ligação entre o topo e a base, como se viu atrás. A liderança de topo pode potenciar ou licenciar este recurso, mas é impossível contornálo, como igualmente terá demonstrado a experiência de Carlos Ghosn na Nissan, no Japão (Ghosn, 2003), embora tendo de despedir 20.000 trabalhadores, responsabilizando pelo desastre social a gestão de topo anterior liderada por Y. Kume.

Os recursos raros e inimitáveis podem também ser alargados ao nível da liderança intermédia, sendo talvez estes a serem determinantes, pelo menos no que respeita às Médias e Grandes Empresas, aspeto não explicitado ainda totalmente pela teoria da RBV (Barney e Wright, 1998). Esta seria, assim, uma das mais-valias desta I/A, tornando-se numa das nossas pistas de trabalho que vimos explorando desde então, e que culminou na publicação da obra de Dias, Lopes e Parreira (2011). Não ter tomado em conta este aspeto determinante da manutenção da coesão e do consenso da liderança intermédia, poderá ter sido determinante, enfim, para a alienação posterior, a capitais estrangeiros, da Portucel Embalagem.

10.4. O contexto interno (ligado à implementação do que viria a ser designado por gestão pelas competências) modificou-se de maneira que parecia, aos olhos de todos, irreversível;

10.5. O contexto externo (ligado às condições do negócio) de perda sucessiva de cota de mercado transformou-se, graças à noção de rede de parcerias em lugar de uma integração pelo mercado, como anteriormente.

Esta noção de rede de empresas constituiu porventura uma das bases do sucesso da I/A: a subcontratação de camionistas para o transporte dos produtos acabados para o armazém dos clientes passou a rede de fornecedores de serviços implicados na resolução de problemas com vantagens económicas mútuas ( 2 cargas/dia em lugar de uma) e um 
sentido do cliente final; os desenhadores subcontratados organizados em cooperativa de serviços (garantindo-se a estabilidade de serviço); a criação de uma microempresa de reparação de paletes (com a resolução de um problema que se eternizava) e com ganhos ecológicos, económicos e de emprego.

11. Em termos de apontamento final, diríamos que, apesar do sucesso extraordinário conseguido, não foi possível garantir a continuidade do Programa a partir dos finais de 1992. Depois de o estagiário licenciado em gestão ter abandonado o trabalho na Portucel Embalagem, no início de 1990, sem ter sido substituído, a segunda "estagiária" (licenciada em psicologia) assegurou sozinha a continuação do Programa de Mudança Organizacional. Esta, inicialmente mostrou-se muito confiante e entusiasmada por poder trabalhar sem a "tutela" dos professores universitários; mas pouco a pouco sentiu-se desanimada, sem o confronto de ideias que o contacto com os professores propiciava e sem o estatuto académico que eles lhes emprestavam. Acabaria por sair, ela própria, cerca de dois anos depois, para se dedicar preferencialmente à sua área de eleição, a do psicodrama. É assim que se perdem oportunidades de ouro, em Portugal, de colaboração duradouras de cooperação entre empresas e universidades. A empresa, em lugar de retirar os ensinamentos devidos da experiência, ainda decidiu abrir um concurso público para apoio da referida técnica. A equipa universitária foi confrontada com a inevitabilidade de concorrer para prossecução do projeto de mudança organizacional contínua. $\mathrm{O}$ concurso seria ganho por uma conhecida empresa de consultoria, mais vocacionada para conseguir a "ambicionada" certificação ISO 9001, e que pouco ou nenhum apoio podia dar à continuidade do projeto participativo como o que foi descrito. Como é evidente, nada nos move contra este processo concursal, em si mesmo. A mudança contínua parece entretanto ser uma matéria demasiado complexa para ser apreendida facilmente, fora de um contexto rigoroso de I/A. Parecia-nos ser assim, nos anos 90, e tudo indica que a gestão da cultura portuguesa continuará a ser, ainda, nos próximos tempos um desafio que irá continuar colocar-se.

Assim, sem um grupo de facilitadores externos (ligados a uma instituição de prestígio, e que podia dialogar de igual para igual com todas as instâncias da empresa), vocacionados para "forçar" a gestão participativa, a pirâmide hierárquica como que retomou progressivamente 
todos "os seus direitos", não sem que entretanto se tenha conseguido suavizar o seu peso anterior.

A cultura portuguesa, de forte pendor hierárquico (inspiradora de configurações organizacionais de tipo napoleónico/ fayolista baseadas no princípio estruturante da obediência e de unidade de comando), parece encontrar-se desprovida dos ingredientes de sucesso das restantes estruturas europeias típicas: as baseadas na ideia de mercado (anglosaxónico), na de máquina (germânica), ou na do respeito profundo da autonomia dos diversos níveis hierárquicos (francesa). Pela desconfiança que caracteriza as relações interindividuais, a cultura portuguesa também não promove um relacionamento hierárquico de cariz paternalista benévolo como é próprio da estrutura oriental, ou de pai de família, como é tipicamente a indiana. Pensamos que uma cultura empresarial eficaz necessitaria, porventura, de um equilíbrio entre todos estes elementos estruturais, em situação de se poder obter um mix variável. Para criar esse mix cultural eficaz, necessitaríamos, no nosso país, de um dispositivo de participação de todos os intervenientes internos e/ou externos/parceiros, em permanência, a partir da noção de mudança contínua (Weick e Quinn, 1999). A ausência de condições de participação abrangente de todos os atores pertinentes, e sobretudo dos colaboradores, desencadeia fenómenos de resistência. $\mathrm{O}$ estudo criterioso deste problema central da participação teria obrigatoriamente de estar assegurado nas escolas e nas organizações portuguesas, sob pena de não ultrapassarmos uma produtividade do trabalho medíocre (cerca de metade da dos UE), normalmente obtida no nosso país.

Entre outras consequências, efetivamente, revelou-se ser muito mais fácil a certificação da empresa, pela ISO 9001, tendo sido, efetivamente, uma das primeiras empresas a dar esse passo. Mas esse progresso foi claramente insuficiente para se evitar o desmembramento da área mais problemática da Portucel E. P. Com a venda da Portucel Embalagem à Sonae Indústria e, posteriormente, à empresa espanhola Europac (Papeles y Cartones de Europa S.A.), começava a era do desmantelamento da estrutura técnica, tornada a área frágil em função do processo de transição para o estrangeiro das áreas mais estratégicas (designadas normalmente pelo conceito de "centros de competências"), como tantas vezes sucede.

Como contraponto, refira-se que as restantes estruturas divisionalizadas da Portucel (floresta, pasta e papel) foram compradas por uma empresa nacional e mantêm-se unidas na Portucel-Soporcel, formando um conglomerado industrial à escala mundial, com o seu centro 
de competências no nosso país. A engenharia de sistemas de robotização do armazém de produtos acabados fez um excelente "produto" (por exemplo, bobines de papel com $60 \mathrm{~km}$ de comprimento por $9 \mathrm{~m} \mathrm{de}$ largura são transformadas e embaladas em resmas de papel de escritório (tipo "navigator"), sem a intervenção de um só operador humano). Este tem sido, entretanto, comercializado a nível internacional.

\section{BIBLIOGRAFIA}

Amabile, T. (1983). The social psychology of creativity: a componential conceptualization. Journal of Personality and Social Psychology, 45 (2), 357-376.

Amabile, T., \& Kramer, S. (2011). The Progress Principle: Using Small Wins to Ignite Joy, Engagement, and Creativity at Work. Cambridge, MA: Harvard Business Review Press.

Amabile, T., \& Kramer, S. (2012). Comment vider le travail de son sens. Expansion Management Review, $\mathrm{n}^{\circ} 145$.

APQC - American Productivity Quality Center (1997). Organizational Change: Managing the Human Side.

www.apcq.org/free/whitepapers/orgchange/.

Ancona, D., Malone, Th. W., Orlikowski, W. J., \& Senge, P. M. (2007).

In Praise of the Incomplete Leader. Harvard Business Review, February, p. 1- 7.

Autissier, D., \& Vandengeon-Derumez, I. (2007). Les managers de première ligne et le changement. Revue Française de Gestion, Mai, nº. 174.

Barbier, R. (1996). La recherche-action. Paris: Anthropos.

Barney, J. B., \& Wright, P. M. (1998). On becoming a strategic partner:

The role of human resources in gaining competitive advantage. Human Resources Management, Spring, Vol. 37, n. 1, 31 - 46.

Beer, M., Eisenstat, R. A., \& Spector, B. (1990). Why Change Programs Don't Produce Change. Harvard Business Review. Nov-Dec, n. ${ }^{\circ} 68$ (6): 158-66.

Beer, M., \& Spector, B. (1993). Organizational Diagnosis: Its Role in Organizational Learning. Journal of Counseling and Development, 71: 642-650. 
Bennis, W., \& Nanus, B. (1985). Leaders, the Strategies for Taking Charge. New York: Harper and Row Publishers.

Bériot, D. (2006). Manager par l'Approche Systémique. Paris: Éditions d'Organisation.

Bertalanffy, K., L. (1993). Théorie Générale des Systèmes. Paris: Dunod.

Bollinger, D., \& Hofstede, G. (1987) Les différences culturelles dans le management: comment chaque pays gère-t-il ses hommes? Paris: Éditions d'Organisation.

Collard, D., \& Suquet, J. B. (2013). Indicateurs de gestion et difficultés de renouvellement du genre professionnel: vertus et limites d'une action sur les indicateurs pour transformer les pratiques professionnelles. Activités, 10 (2): 131-156.

Cravens D. W., \& Piercy, N. F. (1995). The network paradigm and the marketing organization: Developing a new management agenda. European Journal of Marketing, Vol. 29 Iss: 3, pp.7 - 34).

Dias, D., Lopes, A., \& Parreira, P. (2011). Fusões e Aquisições: o papel central da liderança intermédia na gestão do choque de culturas. Lisboa: Editora RH.

Eden, D. (1990). Pygmalion in Management: Productivity as a SelfFulfilling Prophecy. M A: Lexinghton Books.

Eden, D. (1992). Leadership and expectations: Pygmalion effects and other self-fulfilling prophecies in organizations. Leadership Quarterly, 3, 271-305.

Fukuyama, F. (2000), A Grande Ruptura. A Natureza Humana e a Reconstituição da Ordem Social. Lisboa: Quetzal.

Galpin, T. (1996). The Human Side of Change: A Practical Guide to Organization Redesign. San Francisco: Jossey-Bass.

Ghosn, C. (2003). Cidadão do Mundo. São Paulo: Editora A Girafa.

Grosjean, S., \& Bonneville, L. (2011). La communication organisationnelle: approches, processus et enjeux. Montréal: Chenelière Education.

Hollander, E. (1958). Conformity, status, and idiosyncrasy credit. Psychological Review 65 (2): 117-127.

Katzenbach, J. R., \& Smith, D. K. (1993). The discipline of teams. Harvard Business Review, n. 71 (March-April): 111-146.

Kets de Vries, M., \& Miller, D. (1984). The neurotic organization: diagnosing and changing counterproductive styles of management. San Francisco: Jossey Bass. 
Kets de Vries, M., \& Miller, D. (1990). Narcisismo e liderança: uma perspectiva de relações de objetos. Revista de Administração de Empresas, vol.30 no.3, São Paulo, July/Sept: 5-16.

King, A. W., Fowler, S. W., \& Zeithaml, C. P., (2002). Competências organizacionais e vantagem competitiva: o desafio da gerência intermediária. RAE - Revista de Administração de Empresas, Jan./Mar, v. 42, n. 1.

Kotter, J. (1995). Leading change: Why transformation efforts fail. Harvard Business Review. Mars Avril, p.59-67.

Kotter, J. (1996). Liderando Mudança. Editora Campos.

Lascoumes, P. (2004). «La Gouvernementalité: de la critique de l'État aux technologies du pouvoir. Le Portique, 13-14.

Lewin, K. (1959). Psychologie Dynamique. Paris: PUF.

Lopes, A. (2010). A Cultura Organizacional em Portugal: de Dimensão Oculta a Principal Activo Intangível. Gestão e Desenvolvimento, $\mathrm{n}^{\circ} \mathrm{s}$ 17 e 18 , p. 3 - 26.

Lopes, A. (2012). Fundamentos da gestão de pessoas: para uma síntese epistemológica da iniciativa, da competição e da cooperação. Lisboa: Edições Sílabo.

Lopes, A., Dias, D. \& Parreira, P. (2009). Análise de um Processo de Fusão de duas Instituições Públicas da Administração Pública Portuguesa: O Papel Central dos Líderes Intermédios. Economia e Empresa, Série II, $\mathrm{n}^{\circ} 9$.

Lopes, A., Reto, L., \& Nelson, A. (1989). Recursos Humanos e Gestão da Qualidade: uma análise de caso. Revista de Gestão, Jul.: 25-32.

Mabi, C. (2011). "Les conceptions de la participation citoyenne inscrites au sein d'un dispositif de concertation. Étude du débat public CNDP "projet de parc éolien en mer des deux côtes". Communication à la seconde journée doctorale sur la participation du public et la démocratie participative, Ecole des Hautes Etudes en Sciences Sociales de Paris, 18 octobre 2011.

Martin, J. (1992). Cultures in Organizations: Three Perspectives. Oxford University Press.

Mintzberg, H. (1982). Structure et Dynamique des Organisations. Paris: Éditions d'Organisation.

Mintzberg, H. (1986). Le Pouvoir dans les Organisations. Paris: Éditions d'Organisation. 
Mintzberg, H., Ahlstrand, B., \& Lampel, J. (1999). Safari en pays stratégie. L'exploitation des grands courants de la pensée stratégique. Paris: Éditions Village Mondial.

Mintzberg, H., \& Westley, F. (2001). Decision making: it's not what you think. MIT Sloan Management Review, v. 42, n, 3, spring.

Moisdon, J. C. (2008). Regles de Gestion, Outils, Organisation. Le Libellio d'AEGIS, 4(1): 18-27.

Morgan, G. (1986). Images of organization. Califórnia: Sage.

Moscovici, S., \& Zavalloni, M. (1969). The group as a polarizer of attitudes. Journal of Personality and Social Psychology, 12, 125-135.

Moscovici, S., \& Lage, E. (1976). Studies in social influence III: majority versus minotiry influence in a group. European Journal of Social Psychology, 6(2): 149-174).

Neumeier, M. (2003).The brand gap - how to bridge the distance between business strategy and design. New Riders Publishing: Indianapolis.

Oda, E. (2011). Interpretações da cultura japonesa e seus reflexos no Brasil. Revista Brasileira de Ciências Sociais, vol. 26, n. ${ }^{\circ}$ 75: 103117.

Olins, W. (2003). A Marca. Lisboa: Editorial Verbo.

Pascale, R. T., \& Athos, A. G. (1981). The art of Japanese management. New York: Simon \& Schuster).

Pettigrew, A. M., Woodman, R. W., \& Cameron, K. S. (2001). Studying organizational change and development: challenges for future research. Academy of Mangement Journal, 4 : 697-315.

Philippon, Th. (2007). Le capitalisme d'héritiers. La crise française du travail. Paris: éd. du Seuil.

Pitcher, P. (1997). Artistes, artisans et technocrates dans nos organisations. Montréal: Presses HEC — Éditions Québec/Amérique.

Quinn, R. E., \& Cameron, K. (1983). Organizational life cycles and shifting criteria of effectiveness: some preliminary evidence. Management Science, vol. 29, $\mathrm{n}^{\circ}$ 1, January.

Quinn, R. E. (1996). Deep Change: Discovering the Leader Within. San Francisco: The Jossey-Bass Business \& Management Series.

Robbins, S. (1996). Comportamento Organizacional. São Paulo: Prentice Hall.

Sabino, A. N., \& Lopes, A. (2012). O comprometimento organizacional como determinante da voz: um estudo de perfis. Gestão $e$ Desenvolvimento, $\mathrm{n}^{\circ}$ 20: 7-25. 
Sabino, A., Lopes, A., \& Nogueira, F. (2015). Do comprometimento organizacional à satisfação com o trabalho e às estratégias comportamentais: inferências sobre os dois subsistemas de ensino superior em Portugal. Revista Lusófona de Educação, n 31, 33-55.

Sainsaulieu, R. (1977). L'ídentité au travail. Paris: Presses de Sciences Po (P.F.N.S.P.).

Schein, E. (1992). Organizational culture and leadership. San Francisco: Jossey-Bass.

Schumpeter, J. A. (1997). Teoria do Desenvolvimento Econômico, uma investigação sobre lucro, capital, crédito, juros e o Ciclo Económico. São Paulo: Editora Nova Cultural.

Seruya, J. M. (2009). éPT! - A Marca Interna da Portugal Telecom, Gestão da Identidade Organizacional. Cascais: Princípia.

Spector, B., \& Beer, M. (1994). Beyond TQM Programmes. Journal of Organizational Change Management, Vol. 7 Iss: 2: 63 - 70.

Talvio, M., Lonka, K., Komulainen, E., Kuusela, M., \& Lintunen, T. (2013). Una nueva mirada a la formación en eficacia docente de Gordon (TET): un estudio-intervención en el aprendizaje social e emocional del profesorado. Eletronic Journal of Research in Educational Psychology, 11(3): 693-716.

Tap, P. (1988). La société Pygmalion? Intégration sociale et réalisation de la personne. Paris: Dunod.

Vala, J. (1997). Representações Sociais e Percepções Intergrupos. Análise Social, vol. XXXII $\left(1^{\circ}\right), 7-29$.

Vala, J., Lima, M. L., \& Monteiro, M. B. (1987). Conflitos intergrupais em contexto organizacional: problemas de investigação e de intervenção - estudo de caso. Análise Social, vol. XXII (5º), 801-814.

Weick, K. (1998). "Improvisation as a Mindset for Organizational Analysis". Organization Science, vol. 9, p. 543-555.

Weick, K. (2001). Make sense of the organization. Malden: Blackwell Publishing.

Weick, K., \& Quinn, R. E. (1999). Organizational Change and Development. Annual Review of Psychology, n.50, p.361-386.

Walker, D., \& Lambert, L. (1995). Learning and leading theory: A century in the making. In Lambert, L. et al., The constructivist leader (pp. 1-27). New York: Teachers College Press. 